\title{
Rolf Stahel \& Dirk Arnold: Trends in Lung Cancer Treatment and Key Roles of Comprehensive Cancer Centers
}

\section{Rolf Stahel \& Dirk Arnold: Principais Tendências no Tratamento do Cancro do Pulmão e o Papel dos Centros de Cancro Integrados}

Dirk Arnold ${ }^{1}$, Rolf Stahel², Edition: Ana Filipa Marques ${ }^{3}$

\section{ABSTRACT}

On $7^{\text {th }}$ of July 2016, the Update Clinical Oncology event of the Instituto CUF de Oncologia (ICO), organized by Academia CUF at NOVA Medical School, brought together Dirk Arnold and Rolf Stahel, both medical doctors specialized in oncology, to discuss the latest treatment trends and challenges in lung cancer as well as to discuss the key roles and features of benchmarked Cancer Centers.

KEYWORDS: Biomarkers, Tumor; Drug Therapy/trends; Immunotherapy; Lung Neoplasms/therapy; Molecular Targeted Therapy

\section{RESUMO}

No dia 7 de julho de 2016, durante o evento "Update Clinical Oncology" do Instituto CUF de Oncologia (ICO), organizado pela Academia CUF na NOVA Medical School, juntou os médicos especialistas em oncologia Rolf Stahel e Dirk Arnold. Ambos discutiram e partilharam o seu ponto de vista relativamente às mais recentes tendências e desafios do tratamento do cancro do pulmão bem como as principais funções, estruturas e recursos dos mais reconhecidos centros para o diagnóstico e tratamento de cancro.

PALAVRAS-CHAVE: Biomarcadores Tumorais; Imunoterapia; Neoplasias do Pulmão/tratamento; Quimioterapia/tendências; Terapia de Alvo Molecular 


\section{THE ROLE OF IMMUNOTHERAPY IN LUNG CANCER TREATMENT}

Globally, lung cancer is the most common cause of cancer mortality, being responsible for nearly 1 in 5 cancer-related deaths (around 1.6 million people). The two major forms of lung cancer are non-small cell lung cancer (NSCLC) which comprises approximately 85\% of all lung cancers and small cell lung cancer (SCLC). With the background of those numbers, lung cancer is not only a global challenge as this disease has also served as a model for the development of new strategies in cancer treatment.

Cancer has traditionally been treated through surgery, radiotherapy and - within the last decade - with "targeted agents", integrating the increased knowledge about the complex cancer biology and ending in the development of drugs which specifically address these alterations. Following this, according to Rolf Stahel, immunotherapy has now appeared as a further novel reality for patients. This treatment can elicit a person's response against his or her cancer by stimulation of specific mechanisms of the immune system. However, it does not provide a similar benefit to every patient but it offers a great chance - as to whom immunotherapy works, it leads to a much deeper level of anticancer activity for the patient with a much more sustainable benefit than chemotherapy does.

The chances of those new modern immunotherapy approaches can be well described in another frequently diagnosed malignancy too: In malignant melanoma there is scientific proof that up to $40 \%$ of patients may even be cured with immunotherapy. However, the treatment has not been used long enough to definitely make those statements - and it is unclear also due to the limited follow-up of treated patients nowadays, if and how this applies to other tumor types, as lung cancer. Rolf Stahel only dares to say that so far, a good proportion of lung cancer patients have enjoyed long lasting benefits from immunotherapy.

\section{BEYOND IMMUNOTHERAPY: PERSONALIZED TREATMENTS}

Nevertheless, as mentioned above, discoveries in lung cancer treatment are not restricted to immunotherapy. Proving this, personalized treatments with "targeted agents" gained relevance about 10 years ago. By using these, tumors can be molecularly tested, in order to identify the mutations which drive growth and proliferation of the disease, making it specifically treatable with specifically developed agents. Therefore, lung cancer has thus been the example for nearly all malignancies as several highly specific treatments are available for spe- cific mutations. At the moment, the frequency of such mutations is rather low - only $25 \%$ of patients with lung cancer. As Dirk Arnold pointed out, despite that, molecular testing is a novel standard for patients being treated within the ICO lung cancer program.

\section{IMMUNOTHERAPY, INFLAMMATION AND SPECIFIC MUTATIONS: PREREQUISITES FOR PATIENT SELECTION?}

When asked about why immunotherapy with the (so called) "checkpoint inhibitors" and specifically questioned why it is so successful to treat lung cancer and melanoma, compared to other epithelial cancers (where this level of activity is still to be proven), Rolf Stahel explains that immunotherapy performs specifically well when treating the so called inflamed tumors - malignancies where inflammatory processes occur often and seem to play an important role. Lung cancer is one of those tumors.

On the other hand, the more "immunogenic" the tumor type is (e.g. as characterized by showing several mutations) the higher is the likelihood that the patient's own immune system may react to it, and here, as specific immunomodulation may be more successful.

Stahel stated that at the next annual scientific meeting of ESMO (European Society of Medical Oncology), to take place in Copenhagen in early October, new data will be presented and these will show that, for some patients, immunotherapy should even be prescribed first instead of chemotherapy, as it can be much more successful.

Moving forward, Dirk Arnold highlighted an interesting interaction between the inflammation and the immune response. When asked if these should be therapeutically targeted in combination of treatments, Rolf Stahel stated that data exists about this and it has been recently presented at the ESMO Congress on Immuno-Oncology. Rolf Stahel further explained that, on the other hand, tumors with a specific oncogenic driver mutation, thus revealing fewer mutations in total, seem to be less responsive to immunogenic treatments since the immune system recognizes those cells less. Furthermore, the mechanisms which trigger this subset of lung cancers are not the immunogenic.

INSTITUTO CUF DE ONCOLOGIA: SHAPING A CANCER CENTER OF EXCELLENCE

On $6^{\text {th }}$ of July, Dirk Arnold conducted the formal opening of the Instituto CUF de Oncologia (ICO) a comprehensive cancer center, serving all aspects of cancer medicine 
within CUF's network. Rolf Stahel, in his position as the Director of the Comprehensive Cancer Centre of the University of Zürich - and with the insights of his role as the former president of ESMO with its nearly 14,000 members across Europe, being organized in various healthcare environment systems, shared his thoughts on the added benefits - and most relevant structural elements - of those centers. According to him, the "living" of multidisciplinary tumor boards - staffed with competent contributors - is a key factor. He added that it is of utmost importance to ensure that all physicians realize the potential of being part of such an organization, as they are among the most valuable resources of a cancer center. Thus being, it is worth spending some time thinking about a system where all have optimal access to teaching and research facilities. Furthermore, the cancer center should be "marketing orientated" - not only to the patients and relatives who should be made aware of the (obvious) benefits of those "all in one hand" structures, but also referring physicians from both in and outside the network.

\section{ONCOLOGY IN PORTUGAL - A VIEW FROM EUROPE}

Dirk Arnold shared the view that although oncologists and related healthcare professionals are excellently trained and highly motivated, Portugal's visibility within the European oncology landscape is not yet satisfactory. Regarding this, Rolf Stahel concluded that a solution may be to drive efforts into the promotion and organization of major scientific meetings and to trigger an active policy of co-operation with other cancer centers abroad. Dirk Arnold agreed and stated that in addition to this, many Portuguese oncologists recognize how important international co-operation and training are for their own development.
Rolf Stahel added that in order to retain medical professionals of recognized expertise, one must enhance their contribution in Portugal by giving each professional a place to grow depending on their respective potential. In addition to clinical development, access to innovation also plays a key role and therefore a Comprehensive Cancer Center which acts as a center of excellence and reference is a prerequisite.

\section{A GRASP INTO THE FUTURE}

Will cancer become more prevalent and less deadly? From Rolf Stahel's experience, despite all advancements in cancer research, the disease will not disappear. In fact, cancer will be a growing reality - but also life expectancy is increasing as well, with and without cancer. Nevertheless, research together with clinical development as well as innovation will increasingly contribute to make cancer more treatable, and therefore contribute to patient's improved prognosis and higher chance for cure.

CONFLICTS OF INTEREST: The authors have no conflicts of interest to declare.

FINANCING SUPPORT: This work has not received any contribution, grant or scholarship.

CONFLITOS DE INTERESSE: Os autores declaram a inexistência de conflitos de interesse na realização do presente trabalho.

FONTES DE FINANCIAMENTO: Não existem fontes externas de financiamento para a realização deste artigo. 